Zeszyty Naukowe Szkoły Głównej Gospodarstwa Wiejskiego w Warszawie

Problemy Rolnictwa Światowego tom 18 (XXXIII), zeszyt 4, 2018: 395-406 DOI: 10.22630/PRS.2018.18.4.128

Andriy Popovych $^{1}$

Instytut Agroekologii i Gospodarki Przyrodniczej, Narodowa Akademia Nauk Rolniczych Ukrainy

\title{
Zastosowanie modelu grawitacyjnego do analizy międzynarodowego handlu miodem pszczelim
}

\section{The Application of a Gravitational Model for Analyzing of International Trade in Bee Honey}

\begin{abstract}
Synopsis. Celem artykułu jest określenie cech funkcjonowania i identyfikacja trendów w rozwoju światowego rynku miodu. Aby zidentyfikować czynniki wpływające na światowy handel miodem, zastosowano model grawitacyjny, a mianowicie jego odmianę dla pojedynczego produktu. Dane statystyczne dotyczące handlu międzynarodowego pozyskano $\mathrm{z}$ baz światowych organizacji i użyto do ilościowego określenia tego modelu. W wyniku analizy ekonometrycznej danych panelowych zidentyfikowano determinanty światowego handlu miodem i potwierdziła zasadność zastosowania modelu grawitacyjnego do oceny tego rynku.
\end{abstract}

Słowa kluczowe: miód pszczeli, międzynarodowy handel, model grawitacyjny

\begin{abstract}
The aim of the article is to analyze the characteristics of functioning and to identify trends in the development of the global honey market. To analyze the factors affecting global trade in honey, the gravity model was used, namely its variation for a single product. Statistics on international trade from databases of leading international organizations were used to quantify this model. As a result of econometric analysis of panel data, the determinants of global trade in honey were identified and the use of the gravity model was justified in assessing this market.
\end{abstract}

Key words: bee honey, international trade, gravitational model

JEL Classification: F14, Q13, Q17

\section{Wprowadzenie}

Spośród prawie wszystkich naturalnych produktów spożywczych, miód pszczeli jest jednym z najbardziej wyjątkowych pod względem znaczenia dla ludzi i historii produkcji. Biorąc pod uwagę obecny stan rozwoju naukowego i technologicznego, społeczeństwo jest bardzo uzależnione od pszczół, zwłaszcza od wyników ich działalności - zapylania większości roślin rolniczych. Wartość ekonomiczna zapylania głównych upraw przez owady jest 10-15 razy większa niż wartość miodu (Majewski, 2016). Miód i inne produkty pszczele są produktami ubocznymi głównej funkcji pszczół, a przychody uzyskane ze sprzedaży miodu można uznać za wynagrodzenie usług zapylania. Wydajność ekonomiczna pszczelarstwa jest ważnym elementem wspierania wystarczającej liczby pni

\footnotetext{
${ }^{1} \mathrm{PhD}$, Institute of Agroecology and Environmental Management, Metrolohichna 12 Str., 03143, Kyiv, e-mail: apopovych@kse.org.ua; https://orcid.org/0000-0001-9064-9134
} 
pszczelich, a zdolność pszczelarstwa do świadczenia koniecznych usług zapylania zależy bezpośrednio od sytuacji na rynku miodu.

Pszczelarstwo pełni bardzo ważną funkcję interdyscyplinarną, ponieważ miód, pyłek kwiatowy, wosk pszczeli, propolis, mleczko pszczele są pozyskiwane od pszczół, są szeroko stosowane zarówno $\mathrm{w}$ przemyśle spożywczym, jak i farmaceutycznym. W ostatnich latach rola pszczół dla środowiska stała się bardziej widoczna w Europie i Stanach Zjednoczonych w związku z problemem masowej śmierci pszczół (Tapparo i in., 2012). Jednak w krajach będących głównymi producentami i eksporterami miodu główne problemy pszczelarstwa dotyczą sytuacji ekonomicznej, jak: słabe powiązania rynkowe, niska przejrzystość cenowa, niewystarczające umiejętności pracy, ograniczony dostęp do kredytu i niezdolność do przeprowadzania testów jakości (Bradbear, 2009).

Obrót światowego rynku miodu, którego udział w ogólnej wartości produktów pszczelich jest nie mniejszy niż $90 \%$, jest stosunkowo niewielki w porównaniu z innymi sektorami rolnictwa. W 2017 r. wartość produktów pszczelich wytworzonych na świecie wyniosła 8,8 mld USD, w tym miód -8 mld USD. Jednocześnie na rynek światowy dostarczono 690 tysięcy ton miodu o wartości 2,4 mld USD, a w latach 2008-2018 światowy rynek produktów pszczelarskich pod względem wartości wzrastał o $2 \%$ rocznie. Trend ten jest charakterystyczny zarówno dla krajów rozwiniętych, jak i rozwijających się. W omawianym okresie znacznie zwiększył się wywóz miodu z Ukrainy, Nowej Zelandii, Brazylii, Meksyku, Argentyny, Turcji i innych "krajów miodu". Nieznacznie zmniejszony został eksport miodu z Chin i Wietnamu.

Rosnąca świadomość zdrowotna wśród konsumentów na temat korzyści zdrowotnych jest głównym czynnikiem przyczyniającym się do wzrostu globalnego rynku miodu w większości regionów. W ostatnich latach na światowym rynku miodu mają miejsce kardynalne zmiany: rosnące wymagania co do jakości tego produktu, zmieniający się układ sił w pierwszej dziesiątce producentów i eksporterów, nasilająca się konkurencyjna walka między nimi i konflikty handlowe. Globalizacja znacznie zaostrzyła konkurencję o obiecujące rynki, które obejmowały dziesiątki krajów - producentów, eksporterów i importerów miodu.

Jednocześnie, w obliczu globalizacji światowej gospodarki i liberalizacji handlu, rządy wielu krajów podejmują energiczne działania w celu ochrony interesów swoich producentów i eksporterów miodu, aby zapewnić im bezpośrednią i pośrednią pomoc. Włączenie produktów rolnych do handlu międzynarodowego zależy od krajowej polityki rolnej, która rozwija się w sferze produkcji, ochrony importu i ekspansji eksportu (Dascal i in., 2002). Międzynarodowy handel miodem wykazuje spadek udziału w handlu ogółem, ale jednocześnie pozostaje najbardziej chronionym sektorem w wielu krajach, zwłaszcza tych najbardziej rozwiniętych, które prowadzą krajową politykę wsparcia dla lokalnych producentów miodu.

Pszczelarstwo jest szeroko reprezentowane w badaniach akademickich, jednak rynek miodu w perspektywie globalnej jak dotąd nie był szeroko dyskutowany w środowisku akademickim. Większość badań ekonomicznych dotyczących produktów pszczelich jest bezpośrednio związana $\mathrm{z}$ aspektami środowiskowymi. Najczęściej rozpatrywane problemy związane są $\mathrm{z}$ wysokim poziomem wykorzystania chemikaliów w rolnictwie, co negatywnie wpływa na kondycję rodzin pszczelich i jakość miodu, co z kolei negatywnie wpływa na stan ogrodnictwa i produkcji roślinnej oraz możliwości eksportowe krajów produkujących miód (Ören i in., 2010; Yamei i Zhihua, 2012; Adgaba i in., 2014). 
Część artykułów dotyczących ekonomiki pszczelarstwa opiera się głównie na różnych aspektach mikroekonomicznych, w tym na głównych wskaźnikach ekonomicznych produkcji miodu, analizie społeczno-ekonomicznej pszczelarstwa, profilach pszczelarskich i czynnikach wpływających na wprowadzenie ulepszonych technologii pszczelarskich (Vural, 2010; Pîrvuțoiu i Popescu, 2011; Garcia, 2018). Wśród tematów badań znalazła się również budowa modelu pszczelarstwa, który obejmuje dynamikę w ciągu i pomiędzy latami $\mathrm{w}$ populacji pszczół miodnych lub modelowanie rynku usług zapylania przez pszczoły miodne (Rucker i in., 2012; Champetier i in., 2015; Żak, 2017).

Badania empiryczne międzynarodowego handlu produktami rolnymi mogą być oparte na "modelu przyciagania", jednym z najpopularniejszych modeli ekonometrycznych w handlu międzynarodowym, uwzględniającym handel dwustronny jako funkcję wielkości gospodarki partnerów handlowych, położenie geograficzne, koszty transakcji (koszty transportu, koszty administracyjne bariery). Niemniej jednak istnieje tylko kilka badań opartych na modelu grawitacji $\mathrm{w}$ odniesieniu do jednego produktu rolnego lub grupy towarów i, o ile można to ocenić na podstawie dostępnej literatury, żadno z nich nie było powiązane $\mathrm{z}$ rynkiem miodu.

Dlatego głównym celem artykułu jest określenie możliwości wykorzystania modelu grawitacji jako narzędzia do analizy globalnego handlu miodem. Stosując standardowe metody analizy ekonometrycznej danych panelowych, zostanie przetestowana hipoteza, że w odniesieniu do międzynarodowego handlu produktami pszczelarskimi wartość eksportu lub importu danego kraju jest pozytywnie uzależniona od jego PKB, ponieważ produkcja określa podaż towarów przeznaczonych na eksport, PKB kraju importującego, ponieważ określa zdolność produkcyjna, wielkość rynku i popyt na import, i ujemnie z kosztów transportu, które rosną wraz ze wzrostem odległości między krajami. Ponadto oczekuje się, że obecność różnego rodzaju umów handlowych między krajami ma pozytywny wpływ na przepływy eksportowe produktów pszczelich.

Handel miodem jest ważny albo jako potencjalne źródło dochodu, albo jako główne źródło importu tego rodzaju żywności, zwłaszcza, że coraz większa część produkcji miodu jest przedmiotem wymiany międzynarodowej. To dyktuje potrzebę analizy szans i perspektyw na globalnym rynku miodu, badanie "reguł gry" i sytuacji na tym rynku. Potwierdza to znaczenie badania międzynarodowego handlu produktami pszczelimi, który jest ważnym czynnikiem wzrostu gospodarczego, stabilności politycznej i ma kluczowe znaczenie dla krajowych strategii bezpieczeństwa żywnościowego dla wielu krajów rozwijających się. Identyfikacja kluczowych czynników na globalnym rynku miodu pomoże uzyskać pełny obraz rynku, głębiej zrozumieć obecne trendy rynkowe i ocenić przyszłe perspektywy rynkowe dla poszczególnych struktur biznesowych i całych krajów.

\section{Przegląd literatury}

Klasyczna teoria handlu międzynarodowego, oparta na zasadzie przewagi komparatywnej, dostarcza wyjaśnienia międzynarodowej specjalizacji jako przyczyny międzynarodowej wymiany, ale pozostawia poza badaniem szereg czynników, które moga mieć znaczący wpływ na towary i geograficzną strukturę handlu. Luka ta jest wypełniona empirycznymi metodami badań, z których najbardziej znanym jest „model Tinbergena" (Tinbergen i Hekscher, 1962). Model grawitacji jest ekonomiczną analogią prawa Isaaca Newtona, który mówi, że dwie cząstki materii są do siebie przyciągane z siłą $\mathrm{F}_{\mathrm{ij}}$, wprost 
proporcjonalną do iloczynu ich mas $\mathrm{M}_{\mathrm{i}} \mathrm{i} \mathrm{M}_{\mathrm{j}}$, stała grawitacji $\mathrm{G}$, i odwrotnie proporcjonalną do kwadratu odległości $\mathrm{D}_{\mathrm{ij}}$ między nimi:

$$
F_{i j}=G \frac{M_{i}^{\alpha} M_{j}^{\beta}}{D_{i j}^{2}}
$$

Główną ideą stojącą za podejściem grawitacyjnego modelu handlu jest obrót handlu zagranicznego, który jest bezpośrednio zależny od potencjału gospodarczego krajów handlujących oraz od odwrotności odległości między nimi. Klasyczna wersja modelu opiera się na dwóch zmiennych, a mianowicie: produkcie krajowym brutto (PKB), który charakteryzuje wielkość gospodarki oraz geograficzną odległość między krajami handlowymi, wpływającą na koszty transportu. Kolejne pochodne oryginalnego modelu biorą również pod uwagę heterogeniczność firm pod względem produktywności, wyjaśniają zerowy handel wielu krajów i asymetryczne przepływy handlowe, a także badają wpływ innych czynników, takich jak wspólny język, wspólna granica, przynależność do jednego bloku handlowego.

Serrano i Pinilla (2010) dokonali analizy wpływu różnych czynników na dwustronny handel rolny, produkcję i handel ogólny w latach 1963-2000 na reprezentatywnej próbie z 40 krajów stosującą model grawitacyjny. Wyniki wyraźnie pokazują, że niska elastyczność popytu na produkty rolne i produkty żywnościowe, ich niewielki udział $\mathrm{w}$ handlu wewnątrzprzemysłowym, jak również wysoki poziom protekcjonizmu, na który są narażeni, są głównymi przyczynami ich stosunkowo powolnego wzrostu oraz utraty udziału znaczenia produktów rolnych i żywności na rynku międzynarodowym.

Koo i in. (1994) zbudowali model, aby określić czynniki wpływające na światowy handel mięsem i produktami mięsnymi. Teoretycznie uzasadniając możliwość zastosowania modelu grawitacyjnego dla jednej grupy produktów, jednocześnie zauważając, że użycie modelu grawitacyjnego dla jednego produktu lub branży jest możliwe tylko przy użyciu danych panelu. W nowszych badaniach Witt i Witt (1995) skonstruowali model grawitacyjny do szacowania przepływów turystycznych, Walsh (2018) - handlu usługami, Dascal i in. (2002) - handlu winem.

Fontagné $\mathrm{i}$ in. (2005) ocenili wpływ środowiska instytucjonalnego na handel międzynarodowy $\mathrm{w}$ postaci taryf i barier pozataryfowych w handlu oraz stwierdzili, że wymiana handlowa między dwoma krajami zależy od ich mas ekonomicznych i jest negatywnie związana z kosztami wymiany handlowej między nimi. Z kolei Mac Callum i inni (2003) rozważali różne rodzaje czynników wpływających na koszty handlu, a ich wpływ na międzynarodowe przepływy handlowe był w stanie obliczyć koszt przekroczenia granicy dla towarów rolnych.

Djankov i in. (2010) zastosowali model grawitacji do danych Doing Business dotyczących czasów przekraczania granicy między 98 krajami, aby pokazać, że czas przejścia na granicy znacznie zmniejsza dwustronny handel, a jeden dodatkowy dzień zmniejsza eksport o $1 \%$. Według ich badań, łatwo psujące się produkty rolne i przemysłowe są szczególnie wrażliwe na czasy przekraczania granic, a kraje bez dostępu do morza są szczególnie wrażliwe na czasy przekraczania granicy, dla których jeden dodatkowy dzień zmniejsza eksport o 4\%. 
Kucharcukova i in. (2010) wykorzystując rozszerzony model grawitacji wnioskowali, że słaba jakość instytucji gospodarczych $w$ wielu krajach SEE i WNP jest największą przeszkodą dla większej integracji handlowej i potwierdza, że od początku reform rynkowych w 1989 roku, kraje SEE i CIS handlują znacznie mniej ze światową gospodarką niż kraje Europy Środkowo-Wschodniej, które później przystapiły do UE. Autorzy tego badania sugeruja, że poprawa jakości instytucji, poprawa infrastruktury i otwartość na współpracę regionalną są dodatkowymi narzędziami stymulującymi handel między SEE i CIS z resztą świata, a członkostwo w WTO ma pozytywny wpływ na handel, ale średnio mniej niż członkostwo w strefie wolnego handlu.

Hatab i in. (2010) wykorzystali metodę modelu grawitacyjnego do analizy głównych czynników wpływających na wywóz produktów rolnych z Egiptu do głównych partnerów handlowych w latach 1994-2008. Jako niezależne zmienne do analizy wykorzystali PKB krajów partnerskich i PKB per capita w modelu alternatywnym, obecność wspólnego języka państwowego, wspólną granicę i odległość między stolicami oraz współczynnik otwartości gospodarki. Ich wyniki pokazuja, że jeden procent wzrostu PKB w kraju prowadzi do pięciokrotnego wzrostu egipskich przepływów eksportowych. Jednocześnie wzrost PKB na mieszkańca prowadzi do zmniejszenia egipskiego eksportu, co thumaczy się tym, że wzrost gospodarczy i rosnące dochody ludności zwiększaja popyt na wszystkie zwykłe dobra. Współczynnik otwartości gospodarki w wyniku analizy okazał się nieistotny, a obecność wspólnego języka arabskiego i wspólnej granicy przyczyniła się do wzrostu eksportu.

Ozturk i Kalyoncu (2009) empirycznie zbadali wpływ zmienności kursów walutowych na przepływy handlowe sześciu krajów w okresie kwartalnym w latach 1980-2005. Główne wyniki pokazują, że wzrost realnej zmienności kursów walutowych, zbliżając się do niepewności kursu walutowego, ma znaczacy negatywny wpływ na handel w Korei Południowej, Pakistanie, Polsce i Republice Południowej Afryki, ale w dłuższej perspektywie ma pozytywny wpływ na Turcję i Wegry. Wniosek ten jest sprzeczny z wynikami innych badań, które potwierdzają pośredni związek między zmiennością kursów wymiany a handlem międzynarodowym.

Fogarasi (2011) poruszył kwestię wpływu zmienności kursów walut na międzynarodowe przepływy handlowe krajów o gospodarkach w okresie przejściowym w Europie Śodkowej, analizując przypadek eksportu węgierskich produktów rolnych do krajów przeznaczenia eksportowego w latach 1999-2008. W oparciu o model grawitacji, który kontroluje inne czynniki, wyniki pokazuja, że zmienność nominalnego kursu walutowego miała znaczący pozytywny wpływ na handel produktami rolnymi w tym okresie.

Tomanov (2013) przeanalizował również wpływ zmienności kursów wymiany na wyniki eksportowe w Europie Środkowej i Wschodniej poprzez dwustronne przepływy eksportowe z Czech, Słowacji, Węgier i Polski do strefy euro, wykorzystując miesięczne dane szeregów czasowych w latach 1999-2013. Wyniki nie wskazują na istotny zwiazzek między zmiennością kursów wymiany a wynikami eksportowymi w krajach Europy Środkowej, wpływ zmienności kursów walut jest niejednoznaczny.

Grant i Lambert (2008) wykazali, że wpływ umów o wolnym handlu na handel członków w dużej mierze zależy od tego, czy analiza koncentruje się na sektorach rolnych czy pozarolniczych, na konkretnej analizowanej umowie i na długości okresu fazy charakteryzującego prawie całość WTC. Lambert i McKoy (2009), analizujący wpływ różnych umów o wolnym handlu w różnych okresach, pokazali, że przynależność do FTA zazwyczaj zwiększa handel produktami rolnymi i produktami spożywczymi między krajami. Prehn i Brümmer (2011) ustalili, że około 20 międzynarodowych grup 
towarowych handlu jest przedmiotem analizy za pomocą modeli grawitacji, ponieważ skutki ekonomiczne polityk dotyczą przede wszystkim konkretnych produktów.

\section{Dane i metody}

W celu oceny charakteru handlu miodu w kontekście światowych dwustronnych przepływów handlu zagranicznego przeprowadzono analizę za pomocą modelu grawitacyjnego. Główną przewagą komparatywną jest zdolność do wykorzystywania danych rzeczywistych do oceny wrażliwości przepływów handlowych w stosunku do czynników polityki, które nas interesują. Główną wadą ekonometrycznego modelu grawitacyjnego jako narzędzia do analizy efektów integracji jest duża zmienność szacunków, ze względu na wrażliwość modelu na zestaw czynników, pobieranie próbek i metodę oceny.

Podczas budowania modelu grawitacyjnego, niezależnie od tego, czy jest on powszechny, czy też dla konkretnej branży, konieczne jest oparcie się na podstawowym sformułowaniu modelu, uzupełniając je zmiennymi będącymi przedmiotem zainteresowania. Lista zmiennych kontrolnych obejmuje PKB jako zmienną określającą masę kraju partnerskiego, odległość między krajami jako zmienną zastępczą kosztów transportu, udział w globalnych i regionalnych umowach handlowych. W rezultacie model, odzwierciedlający zależność wielkości obrotu miodu od powyższych czynników, ma postać „równania agresji":

$$
X_{i j}=\beta_{0} Y_{i}^{\beta_{1}} Y_{j}^{\beta_{2}} D_{i j}^{\beta_{3}} A_{i j}^{\beta_{n}}
$$

gdzie $\mathrm{X}_{\mathrm{ij}}$ jest obrotem handlu zagranicznego lub eksportem (importem) miodu z kraju i do kraju j; $Y_{i}$ - PKB kraju i; $Y_{j}$ - PKB kraju; $D_{i j}$ - odległość między krajami i oraz j; $A_{i j}$ wszelkie inne czynniki (czynniki), które mogą ułatwić lub utrudnić wymianę handlową między krajami, $w$ tym przypadku udział $w$ związkach zawodowych; $\beta_{n}$ - szacowane elastyczności obrotów handlu zagranicznego w odpowiednich zmiennych

Aby zastosować metodę regresji liniowej, powyższe równanie (2) przekształcono w standardowy logarytmiczny model postaci:

$$
\ln X_{i j}=\beta_{0}+\beta_{1} \ln Y_{i}+\beta_{2} \ln Y_{j}+\beta_{3} \ln D_{i j}+\beta_{4} A_{i j}+\varepsilon_{i j}
$$

gdzie $\mathrm{X}_{\mathrm{ij}}$ jest wielkością dwustronnego handlu miodu między krajami i oraz $\mathrm{j}$; $\mathrm{Y}_{\mathrm{i}}$ - PKB kraju i, $Y_{j}$ - PKB kraju; Dij jest odległością między stolicami krajów i oraz j, a $A_{i j}$ jest zmienną obojętną, odzwierciedlającą przynależność państw i oraz j do preferencyjnego związku zawodowego lub obecność unii celnej, która obejmuje kraje i oraz j.

Aby przeprowadzić empiryczne badanie globalnego handlu miodem, dane ogólne zostały zebrane z 20 krajów, największych importerów miodu na świecie: USA, Niemcy, Japonia, Wielka Brytania, Francja, Chiny, Włochy, Belgia, Hiszpania, Holandia, Polska, Australia, Hongkong, Szwajcaria, Kanada, Szwecja, Singapur, Dania, Portugalia, Irlandia, Grecja, Malezja, Kuwejt, Finlandia, Rumunia ${ }^{2}$, zaangażowanych w handel zagraniczny ze wszystkimi innymi krajami i między sobą. Ponieważ zastosowanie modelu grawitacji w odniesieniu do poszczególnych produktów z punktu widzenia czynników popytu i

2 http://agriexchange.apeda.gov.in/product_profile/Major_Imporing_Countries.aspx?categorycode=0408. 
podaży, które różnią się od zagregowanych przepływów handlowych, wymaga użycia danych panelowych, badanie przeprowadzono na szeregach przestrzenno-czasowych za lata 2012-2016. Wybór tego przedziału czasowego wynikał z dostępności danych, a także z faktu, że w tym okresie brak jest drastycznych zmian wskaźników dotyczących wstrząsów gospodarczych podobnych do kryzysu z 2008 r. Próba składa się z 3428 obserwacji.

Źródłem danych o dwustronnym handlu miodem w krajach, zmienną zależną, była baza danych FAO. W przypadku zmiennych kontrolnych wykorzystano PKB krajów partnerskich, a jako źródło danych wybrano bazę danych Światowego Wskaźnika Rozwoju Światowego. Koszty transportu i dostępność preferencyjnych warunków handlu między krajami zostały pobrane $\mathrm{z}$ baz danych CEPII DATABASE i UN Comtrade.

Jako odległość między eksporterem a importerem została użyta odległość między stolicami dwóch krajów, jako głównymi ośrodkami gospodarczymi krajów. Przy pomocy zmiennych fikcyjnych na podstawie podejścia binarnego przetestowano jaki wpływ ma czynnik istnienie umów dwustronnych dotyczących preferencyjnego lub bezcłowego handlu między krajami lub należących do jednej unii handlowej i gospodarczej.

Tabela 1. Charakterystyka danych

Table 1. Data characteristics

\begin{tabular}{c|ccccc}
\hline Zmienna & Obserwacje & Średnia & Odch. standardowe & Min & Max \\
\hline exim & 3428 & 2504.697 & 9094.639 & 0 & 152079 \\
gdp & 3428 & 13848.38 & 18581.12 & 218.2835 & 108600.9 \\
dist & 3428 & 8481.799 & 4703.571 & .9951369 & 19951.16 \\
pol & 3428 & .1743862 & .379445 & 0 & 1 \\
\hline
\end{tabular}

Źródło: obliczenia własne.

Aby uzyskać bardziej szczegółową analizę międzynarodowego handlu miodem, oprócz wspomnianego zestawu danych $\mathrm{z}$ tych samych źródeł i w tym samym okresie, zebrano informacje na temat przepływów handlowych produktów pszczelarskich dla dwóch krajów: Ukrainy i Polski. Zestaw danych dotyczących Ukrainy zawiera 190 obserwacji dotyczacych sprzedaży eksportowej miodu ukraińskiego na rynku międzynarodowym, ponieważ przywóz miodu na Ukrainę był niewielki. Baza danych o obrotach polskich miodu obejmuje 333 obserwacje, wśród których znajdują się wskaźniki zarówno eksportu, jak i importu.

\section{Wyniki badań}

W ramach modelu grawitacji handlu międzynarodowego oceniono oszacowanie równania regresji (3). Do dalszej analizy model grawitacyjny wybrał próbki danych dla 20 krajów - największych importerów miodu, a także częściowo zbiory danych dla Ukrainy i Polski. Biorąc pod uwagę tę zależność między wskaźnikami, można skonstruować równania odzwierciedlające istotę "grawitacji" dla importu dla wspólnego zestawu danych, eksportu dla Ukrainy i handlu zagranicznego miodu, czyli eksportu i importu dla Polski.

Wybierając metodę oceny modelu do analizy przepływów miodu eksportowoimportowego, dokonano porównania między modelem $\mathrm{z}$ deterministycznymi indywidualnymi efektami a losowymi indywidualnymi efektami. Pomiędzy modelem z deterministycznymi indywidualnymi efektami a losowymi indywidualnymi efektami 
wybór padł na model $\mathrm{z}$ deterministycznymi indywidualnymi efektami. Wyniki testu Hausmana, którego celem było porównanie modeli z deterministycznymi i losowymi indywidualnymi efektami, nie pozwoliły na odrzucenie hipotezy zerowej o równości wyników ocen uzyskanych przez modele, a zatem nie mógł pomóc w wyborze pomiędzy tymi specyfikacjami. Jednak model z deterministycznymi indywidualnymi efektami opiera się na założeniu, że obserwacje w próbce mają charakter unifikujący, co jest prawdziwe w przypadku próbki.

Tabela 2. Lista zmiennych

Table 2. List of variables

\begin{tabular}{c|l}
\hline Parametr & \multicolumn{1}{|c}{ Zmienna } \\
\hline$\beta 1$ & PKB kraju i \\
$\beta 2$ & PKB kraju j \\
$\beta 3$ & Odległość między stolicami krajów i oraz j \\
$\beta 4$ & Dummi ze względu na istniejącą preferencyjną umowę handlową między krajem i oraz j \\
$\beta 5$ & Dummi za istniejącą preferencyjną umowę handlową między krajem i oraz j w latach 2015-2016 \\
\hline
\end{tabular}

Źródło: opracowanie własne.

W tabelach 2-4 przedstawiono wyniki estymacji regresji współczynników równania handlu zagranicznego miodu w latach 2012-2016 w trzech modelach najmniejszych kwadratów oszacowanych za pomocą pakietu ekonometrycznego STATA.

Tabela 3. Wyniki oceny równania dla 20 krajów - największych importerów miodu

Table 3. Results of the evaluation of the equation for 20 countries - the largest honey importers

\begin{tabular}{c|cccc}
\hline Parametr & Współczynnik & Błąd stand. & t-Statistic & p-value \\
\hline$\beta 0$ & .0309205 & .0770057 & 0.40 & 0.688 \\
$\beta 1$ & .9398199 & .0071391 & 131.64 & 0.000 \\
$\beta 2$ & .8462465 & .0070224 & 120.51 & 0.000 \\
$\beta 3$ & -.9912178 & .0185748 & -53.36 & 0.000 \\
$\beta 4$ & .5395641 & .051909 & 10.39 & 0.000 \\
Number of obs & & & 3428 & \\
F(4,3421) & & 503.78 & & \\
Prob $>$ F & & 0.0000 & & \\
R-sq overall & & 0.7500 & \\
\hline
\end{tabular}

Źródło: obliczenia własne.

Wyniki oszacowania równania regresji dla zestawu danych dotyczących 20 największych importerów miodu na świecie przedstawione $\mathrm{w}$ tabelach pokazują, że czynniki PKB kraju eksportującego, PKB kraju importującego, odległość między krajami i przynależność do FTA są znaczące przy 99\% przedziale ufności. Znaki przy współczynnikach regresji między wielkościami importu a powyższymi czynnikami odpowiadają założeniom ograniczeń grawitacyjnych, to znaczy potwierdzają spełnienie współzależności leżących u podstaw modelu grawitacyjnego. 
Tabela 4. Wyniki oceny równania dla Ukrainy

Table 4. Results of the evaluation of the equation for Ukraine

\begin{tabular}{c|cccc}
\hline Parametr & Współczynnik & Błąd stand. & t-Statistic & p-value \\
\hline$\beta 0$ & .0889591 & .0314087 & 2,83 & 0.005 \\
$\beta 1$ & .9585429 & .0063464 & 151.04 & 0.000 \\
$\beta 2$ & .8472751 & .0063216 & 134.03 & 0.000 \\
$\beta 3$ & -1.008063 & .017464 & -57.72 & 0.000 \\
$\beta 4$ & .4412589 & .04982 & 8,86 & 0.000 \\
$\beta 5$ & .2511433 & .0521221 & 4.82 & 0.000 \\
Liczba obserwacji & & & 190 & \\
F(4,183) & & 582.26 & & \\
p-value (> F) & & & 0.0000 & \\
$\mathrm{R}^{2}$ & & & 0.6977 & \\
\hline
\end{tabular}

Źródło: obliczenia własne.

Aby oszacować równanie dla zbioru danych dotyczących eksportu miodu na rynek światowy z Ukrainy, model zmodyfikowano tak, aby odzwierciedlał obserwowane nielosowe odchylenia. Zmodyfikowany model ma inną zmienną atrapową dla danych dotyczących 2015 i 2016 r., Czyli okresu obowiązywania umowy stowarzyszeniowej między Ukrainą a Unią Europejską. Wprowadzona zmienna równa jednostce za te lata oszacuje wpływ umowy na wywóz miodu z Ukrainy. Model nadal obejmuje czynniki PKB krajów przeciwnych i ich oddalenie od wybranego kraju eksportującego - importera, udział $\mathrm{w}$ umowie o wolnym handlu. Zgodnie z oczekiwaniami udział w umowie o wolnym handlu pozytywnie wpłynął na przepływy importowe miodu, ale w początkowej wersji modelu znaczenie wynosiło około $90 \%$. Zatem włączenie do modelu dodatkowej zmiennej fikcyjnej doprowadziło do zauważalnej poprawy istotności statystycznej, która okazała się być poniżej poziomu krytycznego.

Tabela 5. Wyniki oceny równania dla Polski

Table 5. Results of the evaluation of the equation for Poland

\begin{tabular}{|c|c|c|c|c|}
\hline Parametr & Współczynnik & Błąd stand. & t-Statistic & p-value \\
\hline$\beta 0$ & .0177934 & .0206764 & 0.86 & 0.389 \\
\hline$\beta 1$ & .9222838 & .0260529 & 35.40 & 0.000 \\
\hline$\beta 2$ & .9416122 & .0260529 & 36.14 & 0.000 \\
\hline$\beta 3$ & -.1458999 & .0453851 & $-3,21$ & 0.001 \\
\hline$\beta 4$ & .336971 & .0339237 & 9.93 & 0.000 \\
\hline Liczba obserwacji & \multicolumn{4}{|c|}{333} \\
\hline $\mathrm{F}(4,326)$ & \multicolumn{4}{|c|}{539.53} \\
\hline p-value $(>F)$ & \multicolumn{4}{|c|}{0.0000} \\
\hline $\mathrm{R}^{2}$ & \multicolumn{4}{|c|}{0.7048} \\
\hline
\end{tabular}

Źródło: obliczenia własne. 
Ocena modelu międzynarodowego zbioru danych dotyczących miodu w Polsce wykazuje duże znaczenie, w tym na poziomie istotności $0,1 \%$ wszystkich czynników oceny: współczynniki dla PKB kraju eksportującego, dla PKB kraju importującego, dla odległości, a także współczynnik determinacji, charakteryzujące adekwatność modelu.

Można zauważyć, że we wszystkich modelach wszystkie czynniki były znaczące na poziomie istotności 0,1. Badanie potwierdziło, że międzynarodowy handel miodem podlega ogólnym zasadom, przestrzega ogólnych wzorców ekonomicznym: na eksport i import miodu w danym kraju duży wpływ ma skala ekonomiczna krajów handlujących, W szczególności kraju wywozu, ponieważ zależność od PKB kraju importującego jest mniej elastyczna, a odległość geograficzna partnera handlowego ma ujemny wpływ. We wszystkich przypadkach umowy o wolnym handlu, umowy o integracji, związki celne mają pozytywny (o około 25-50\%) wpływ na wielkość międzynarodowego handlu miodu.

Jednocześnie niektóre wskaźniki mają odchylenia od oczekiwanych wartości w dół. Współczynnik dla terminu odpowiadającego odległości dla Polski jest znacznie mniejszy niż dla grupy największych importerów i dla Ukrainy. Należy zauważyć, że ocena zależności między wielkością przywozu a odległością zwykle maleje, tj. rola kosztów transportu słabnie, głównie za sprawą wzrostu importu z Chin. Jak wynika z otrzymanych obliczeń, spadek współczynnika regresji między wielkością przywozu a odległością między krajami (według modułów) sugeruje, że dystans między krajami stopniowo traci na znaczeniu. Może to być związane ze zmniejszeniem kosztów transportu towarów i świadczenia usług. Z drugiej strony jednak może to wynikać z faktu, że import z krajów towarów, dla których istnieje zapotrzebowanie niezależnie od kosztów transportu, lub gdy importuje się z Chin, taniość towarów rekompensuje koszty transportu.

Uzyskane wyniki sugerują, że szacunki wzrostu wolumenu wymiany handlowej oparte na grawitacyjnym modelu dwustronnego handlu międzynarodowego mieszczą się w optymistycznych oczekiwaniach rządów. Optymistyczną prognozę można wprowadzić przy zachowaniu dynamiki wzrostu nominalnego PKB lub zawarcia umowy o wolnym handlu. Należy również pamiętać, że szacunki uzyskane w wyniku analizy potencjalnej wielkości międzynarodowego handlu miodu opierają się na światowych tendencjach rozwoju stosunków dwustronnych zidentyfikowanych w analizie modelu grawitacji, którego siła predykcyjna może jednak nie być wystarczająco duża dla niestabilnych gospodarek.

\section{Podsumowanie}

Rezultatem badań jest skonstruowany i oceniony zbiór modeli, w oparciu o które szacowany i prognozowany jest handel miodu. W ramach badania zbudowano grawitacyjne modele przepływów eksportu i importu miodu dla importu dwudziestu krajów największych importerów miodu na świecie, eksportu z Ukrainy i obrotów handlu zagranicznego Polski. Aby ocenić równania regresji, zostały użyte podstawowe dane dotyczące przepływów handlowych wywozu i przywozu miodu z każdego kraju wraz z resztą grupy, dane o PKB krajów partnerskich, odległość między stolicami krajów, udział w związkach handlowych w okresie 2012-2016. Wyniki empirycznych testów modelu wskazują na istotny wpływ wszystkich powyższych czynników na bilateralny bilans w handlu miodu. W wyniku analizy regresji ustalono, że przepływy handlowe są w sposób pozytywny zależne od PKB obu krajów i w przypadku braku barier handlowych i negatywnie zależą od odległości między krajami. 
Chociaż model grawitacji jest odpowiednią platformą dla badaczy zajmujących się analizą handlu międzynarodowego, jego użycie wiąże się też z pokonaniem potencjalnych problemów. Znaczna liczba badań z wykorzystaniem modelu grawitacyjnego określonych produktów koncentruje się na produktach podstawowych, a skala powinna zostać rozszerzona na produkty $\mathrm{w}$ sektorze drugorzędnym gospodarki. $\mathrm{Z}$ drugiej strony model grawitacji jest kluczowym narzędziem dla badaczy zainteresowanych skutkami polityk związanych z handlem. Zapewnia wygodną bazę testową, w której można ocenić wpływ na handel różnych dodatkowych zmiennych zawartych w modelu. Model ten może być wykorzystywany do badania skutków umów o wolnym handlu, które mogą oferować korzystną politykę handlową dla krajów eksportujących i importujących. Przyszłe badania mogą również dotyczyć aspektu metodologicznego modelu grawitacji, który jest nadal względnie ograniczony.

\section{Literatura}

Adgaba, N., Al-Ghamdi, A., Shenkute, A. G., Ismaiel, S., Al-Kahtani, S., Tadess, Y., ... Abdulaziz, M. Q. A. (2014). Socio-economic analysis of beekeeping and determinants of box hive technology adoption in the Kingdom of Saudi Arabia. J. Anim. Plant Sci, 24(6), 1876-1884.

Bradbear, N. (2009). Bees and their role in forest livelihoods: a guide to the services provided by bees and the sustainable harvesting, processing and marketing of their products. Non-wood forest products, (19).

Champetier, A., Sumner, D.A., Wilen, J.E. (2015). The bioeconomics of honey bees and pollination. Environmental and Resource Economics, 60(1), 143-164.

Dascal, D., Mattas, K., Tzouvelekas, V. (2002). An analysis of EU wine trade: a gravity model approach. International Advances in Economic Research, 8(2), 135-147.

Fogarasi, J. (2011). The effect of exchange rate volatility upon foreign trade of Hungarian agricultural products. Studies in Agricultural Economics, 113(1), 1-14

García, N.L. (2018). The Current Situation on the International Honey Market. Bee World, 95(3), 89-94.

Grant, J.H., Lambert, D.M. (2008). Do regional trade agreements increase members' agricultural trade? American Journal of Agricultural Economics, 90(3), 765-782.

Hatab, A.A., Romstad, E., Huo, X. (2010). Determinants of Egyptian agricultural exports: A Gravity model approach. Modern Economy, 1(03), 134. Babecká-Kucharčuková, O., Babecký, J., Raiser, M. (2010). A Gravity Approach to Modelling International Trade in South-Eastern Europe and the Commonwealth of Independent States: The Role of Geography, Policy and Institutions. Czech National Bank, Research Department.

Khan, M., Hossain, M.I. (2010). Model of Bilateral Trade Balance: Extensions and Empirical Tests. Economic Analysis and Policy, 40(3), 377.

Koo, W.W., Karemera, D., Taylor, R. (1994). A gravity model analysis of meat trade policies. Agricultural Economics, 10(1), 81-88.

Lambert, D., McKoy, S. (2009). Trade creation and diversion effects of preferential trade associations on agricultural and food trade. Journal of Agricultural Economics, 60(1), 17-39.

Majewski, J. (2016). Pszczoły w biogospodarce-znaczenie i wartość ekonomiczna (Bees in bioeconomy - role and economic value). Roczniki Naukowe Stowarzyszenia Ekonomistów Rolnictwa i Agrobiznesu, 18(4), 172-177.

Ören, N., Alemdar, T., Parlakay, O., Yılmaz, H., Seçer, A., Güngör, C., ... Gürer, B. (2010). An economic analysis of beekeeping activities in Adana. Publication no. 178. Ankara. Agricultural Economic and Policy Development Institute.

Pîrvutoiu, I., Popescu, A. (2011). Analysis of Romania’s honey market. Scientific Papers Animal Science and Biotechnologies, 44(2), 500-503.

Prehn, S., Brümmer, B. (2011). Estimation issues in disaggregate gravity trade models (No. 1107). Diskussionspapiere//Department für Agrarökonomie und Rurale Entwicklung.

Rucker, R.R., Thurman, W. N., Burgett, M. (2012). Honey bee pollination markets and the internalization of reciprocal benefits. American Journal of Agricultural Economics, 94(4), 956-977.

Serrano, R.L., Pinilla, V. (2012). The long-run decline in the share of agricultural and food products in international trade: a gravity equation approach to its causes. Applied Economics, 44(32), 4199-4210. 
Tapparo, A., Marton, D., Giorio, C., Zanella, A., Soldà, L., Marzaro, M., ... Girolami, V. (2012). Assessment of the environmental exposure of honeybees to particulate matter containing neonicotinoid insecticides coming from corn coated seeds. Environmental Science \& Technology, 46(5), 2592-2599.

Tinbergen, J. Hekscher, A. (1962). Shaping the World Economy. Suggestions for an International Economic Policy. [With Forew. Bf A. Hekscher]. Twentieth Century Fund.

Tomanová, L. (2013). Volatility and the Foreign Trade in CEEC. In Proceedings of the First International Congress on Economics (pp. 649-664).

Vural, H. (2010). Socio-economic analysis of beekeeping and the effects of beehive types on honey production. African Journal of Agricultural Research, 5(22), 3003-3008.

Witt, S.F. Witt, C.A. (1995). Forecasting tourism demand: A review of empirical research. International Journal of Forecasting, 11(3), 447-475.

Walsh, K. (2006). Trade in services: does gravity hold? A gravity model approach to estimating barriers to services trade. IIIS Discussion Paper Series No. 183. Pobrano z: https://ssrn.com/abstract=945335

Yamei, Q. Zhihua, Y. (2012). Analysis on the export and blocking factors for Chinese bee product [J]. China's Livestock Industry, 12, 19-23.

Żak, N. (2017). Honey market in the opinion of young consumers. Handel Wewnętrzny, 1 (366), 424-438.

Do cytowania / For citation:

Popovych A. (2018). Zastosowanie modelu grawitacyjnego do analizy międzynarodowego handlu miodem pszczelim. Problemy Rolnictwa Światowego, 18(4), 395-406;

DOI: 10.22630/PRS.2018.18.4.128

Popovych A. (2018). The Application of a Gravitational Model for Analyzing of International Trade in Bee Honey (in Polish). Problems of World Agriculture, 18(4), 395-406;

DOI: 10.22630/PRS.2018.18.4.128 